Community: volume 6, Nomor 2, Oktober, 2020

p-ISSN: 2477-5746 e-ISSN: 2502-0544

\title{
Permasalahan Pemberdayaan Masyarakat Pertanian Melalui Usaha Tani di Nagari Pasir Talang
}

\author{
Tegar C Bahari', Waza Karia Akbar ${ }^{2}$, Sri Rahmadani ${ }^{3}$ \\ ${ }^{1}$ Program Studi Pendidikan Sosiologi STKIP PGRI Sumatera Barat \\ ${ }^{2}$ Program Studi Pendidikan IPS STKIP PGRI Sumatera Barat \\ ${ }^{3}$ Program Studi Pendidikan Sosiologi STKIP PGRI Sumatera Barat \\ Email: ${ }^{2}$ Wazasolok@gmail.com
}

\begin{abstract}
The agricultural sector is the main center in rural areas. This happens because the community works to cultivate the land in their environment. With the formation of farmer groups, community agricultural activities will be more structured. This can be found in the community in Nagari Pasir Talang. The community at work is more structured. but all things did not go well because there were obstacles that must be overcome so that it is interesting to research. This study uses a qualitative type in data collection. theory developed by Robert K Merton. The results showed that the community's capacity was still weak in developing and managing a farm which was formed in the form of farmer groups. so that there are farmer groups that can survive and some die by themselves. The management ability of the community is still very weak in the citrus farmer groups in Nagari Pasir Talang.
\end{abstract}

Keywords: Gapoktan; Community; Farmer

\section{PENDAhuluan}

Penduduk Indonesia yang berdomisili di daerah pedesaan pada umumnya memiliki mata pencaharian disektor pertanian. Sektor pertanian merupakan sektor yang strategis dan berperan penting dalam perekonomian nasional dan kelangsungan hidup masyarakat, penyedia lapangan kerja, dan penyediaan pangan dalam negeri. Pembangunan ekonomi di sektor pertanian mempunyai peranan yang sangat penting dalam perkembanngan ekonomi, karena memberi sumbangan lebih besar pembangunan nasional. Upaya untuk meningkatkan kemampuan kelompok dalam mendukung pengembangan sektor pertanian sangatlah di tuntut karena petani merupakan pelaku utama yang mempengaruhi produksi di bidang pertanian. Lahan pertanian tanaman pangan dan holtikultura diarahkan untuk mengujutkan pertanian tangguh, maju dan efisien oleh kemampuan guna mendorong pertumbuhan sektorsektor terkait dalam sisitem perekonomian (Alhafis., 2016).

Kelompok tani yaitu sebagai kumpulan orang-orang yang bekerja sebagai petani dalam suatu wilayah atas dasar keserasian dan kebutuhan bersama, sebagai wadah kerja sama antara anggota kelompok. Kelompok tani di dirikan untuk memecahkan permasalahan yang di hadapi oleh petani yang tidak bisa di selesaikan oleh individu (Mawarni, Eka, Mahludin Baruwadi, 2017). Kumpulan petani yang terikat secara non formal dan di bentuk atas dasar kesamaan, kepentingan, kesamaan 
Community: volume 6, nomor 2, Oktober, 2020

p-ISSN: 2477-5746 e-ISSN: 2502-0544

kondisi lingkungan(sosial, ekonomi, sumber daya), keakraban dan keserasian serta mempunyai pimpinan untuk mencapai tujuan yang sama.

Pembentukan kelompok tani bertujuan untuk meningkatkan kemampuan petani dalam menghadapi berbagai permasalahan pertanian. Beberapa permasalahan yang sering di hadapi oleh para petani adalah modal, tenaga kerja, serta minimnya pengetahuan petani dalam proses produksi. Seperti yang kita ketahui masyarakat Indonesia sejak dahulu sudah terbiasa berkerja berkelompok dengan bentuk yang sesui dengan budaya dan kondisi lokal yang ada. Dari sisi petani dengan berkelompok akan lebih mudah mencapi tujuan-tujuan yang di inginkan, di bandingkan dengan bekerja sendiri atau perorangan. Hal ini di karenakan dengan kegiatan berkelompok, petani bisa saling bertukar pikiran pengalaman serta pengetahuan. Selain itu kelompok akan membangun solidaritas antar sesama petani (Triwidarti, 2015).

Kondisi geografis sebagian besar penduduk di Nagari Pasir Talang berprofesi sebagai petani, ada yang mengelola lahannya secara individu ada juga yang tergabung dalam kelompok tani. Kelompok tani merupakan salah satu program pemerintah, di buat untuk meningkatkan perekonomian dan pendapatan anggota kelompok, dan mempermuda kelompok dalam mengolah pertanian secara bersama yaitu dalam bentuk kelompok yang terdiri dari 15 sampai 20 orang anggota. Nagari Pasir Talang memiliki 12 kelompok tani sampai dengan tahun 2019 yang telah di kukuhkan oleh Pemerintahan Pasir Talang.

Table 1.1 Kelompok Tani Di Nagarian Pasir Talang Tahun 2019

\begin{tabular}{|l|l|l|l|c|c|}
\hline No & $\begin{array}{c}\text { Nama Kelompok } \\
\text { Tani }\end{array}$ & \multicolumn{1}{|c|}{ Alamat } & \multicolumn{1}{|c|}{ Ketua } & $\begin{array}{c}\text { Tahun } \\
\text { Berdiri }\end{array}$ & $\begin{array}{c}\text { Jumlah } \\
\text { Anggota }\end{array}$ \\
\hline 1 & Usaha Baru & P. Talang & Benriono & 2012 & 20 \\
\hline 2 & Aman Makmur & Tigo Lareh & Djusmanely.E & 2013 & 20 \\
\hline 3 & Tunas Harapan & Tigo Lareh & Reni Anwar & 2012 & 20 \\
\hline 4 & Hidup Baru & Mpl & Ramadhan & 2011 & 20 \\
\hline 5 & Suka Maju & Panai & Buswardi & 2009 & 20 \\
\hline 6 & Sikumbang Maju & Tigo Lareh & Yendri & 2013 & 20 \\
\hline 7 & Semoga Jaya & Panai & Sunir Abas & 2012 & 20 \\
\hline 8 & Ande Bapak & Sipanjang & Katik. S & 2011 & 20 \\
\hline 9 & Tunas Muda & Panai & Adrial & 2012 & 20 \\
\hline 10 & Berkat Yakin & B. Pagu & Ali Amran & 2014 & 20 \\
\hline 11 & Batang Pagu S & B .Pagu & Syahbudin & 2010 & 20 \\
\hline 12 & Bukit kumpu & sipanjang & Doni arianto & 2013 & 20 \\
\hline
\end{tabular}

Latar belakang berdirinya Kelompok Tani berdasarkan program yang dibuat oleh pemerintah. Berdasarkan hasil penelitian di kantor Wali Nagari Pasir Talang pada tanggal 20 maret 2019 peneliti mewawancarai langsung Wali Nagari Pasir 
Community: volume 6, nomor 2, Oktober, 2020

p-ISSN: 2477-5746 e-ISSN: 2502-0544

Talang Bapak Novri Wandra (45 tahun), menurut beliau syarat pengukuhan suatu kelompok harus berdasarkan ketetapan yang telah di tentukan, salah satunya harus mempunyai tujuan di dirikannya kelompok tersebut, dan harus memiliki anggota kelompok. Kelompok tani berdiri berdasarkan kesepakatan bersama yang diawali dengan musyawarah masyarakat, di mana tujuan utama berdirinya kelompok tani adalah sebagai sarana untuk memajukan usaha pertanian kearah yang lebih baik.

Tabel 1.2 Jenis Usaha Kelompok Tani

\begin{tabular}{|l|l|l|}
\hline No & Nama Kelompok & Jenis Usaha Tani \\
\hline 1 & Usaha Baru & Berternak Bebek \\
\hline 2 & Aman Makmur & Sawah \\
\hline 3 & Tunas Harapan & Jeruk Manis \\
\hline 4 & Hidup Baru & Sawah \\
\hline 5 & Suka Maju & Jeruk Manis \\
\hline 6 & Sikumbang Maju & Sawah \\
\hline 7 & Semoga Jaya & Jeruk Manis \\
\hline 8 & Ande Bapak & Sawah \\
\hline 9 & Tunas Muda & Jeruk Manis \\
\hline 10 & Berkat Yakin & Sapi \\
\hline 11 & Batang Pagu S & Cabe \\
\hline 12 & Bukit Kumpu & Cabe \\
\hline
\end{tabular}

Beragam permasalahan yang di hadapi oleh kelompok tani sehingga berpengaruh terhadap keberlangsungan kelompok tersebut. Pada saat kelompok tani bermasalah maka akan menimbulkan kerugian bagi masing-masing anggota kelompoknya, di saat kelompok tani tersebut tidak aktif lagi akan mempengaruhi anggotanya, misalnya di saat tergabung dalam kelompok banyak bantuan-bantuan yang di dapat dari dinas pertanian setempat, seperti bantuan bibit tanaman, ikut serta dalam sekolah lapangan yang di adakan oleh penyulu, di mana dalam kegiatan ini bnyak ilmu yang dapat kita dapatkan seperti di ajarkan cara menanam jeruk, merawar jeruk, pemupukan, dan sampai cara panen jeruk. Ketika kelompok tani mengalami kemunduran berdampak pada anggota kelompok tani tersebut, bantuan-bantuan dan pelatihan-pelatihan yang pernah mereka dapatkan, sudah pasti tidak mereka dapatkan lagi di karenakan kelompok tani tidak aktif lagi. Bukan hanya itu, sesuai dnagn surat pengukuhan di mana tertera di dalamnya fungsi dan tujuan berdirinya kelompok tani salah satunya untuk membangun kualitas hidup anggota kelompok melalui pertanian tidak tercapai lagi (Akbar, 2018). Sehingga menarik untuk diketahui kendala dan permasalahan yang dihadapi oleh kelompok tani dalam mengembangkan usaha tani dalam masyarakat.

\section{TINJAUAN PUSTAKA}


Teori fungsionalisme structural dari Robert King Merton bahwa analisis fungsional-struktural berfokus pada kelompok-kelompok, organisasi-organisasi, masyarakat dan kebudayaan. Merton juga mengatakan bahwa setiap objek dapat di tundukkan ke pada fungsional struktural harus menggambarkan suatu item yang di standarkan (yakni, terpola dan berulang) yang di maksud merton adalah peran-peran sosial pola-pola kelembagaan proses-proses sosial pola-pola budaya emosi-emosi yang terpola secara budaya, norma-norma sosial, organisasi kelompok, struktur sosial alat-alat pengendalian sosial dan sebagainya (Ritzer, 2012).

Adapun menurut Merton fungsionalisme stuktural juga melihat fungsi-fungsi yang merupakan konsekuensi-konsekuensi yang di amati untuk adaptasi atau penyesuaian suatu sistem tertentu. Oleh karena itu, ada satu ideologi yang jelas ketika orang hanya berfokus pada adaptasi atau penyesuian, karna mereka merupakan konsekuensi-konsekuensi positif. Perlu di ketahui bahwa fakta sosial yang satu dapat mempunyai konsekuensi-konsekuensi negative untuk fakta sosial yang lain. Merton juga mengatakan bahwa konsep disfungsi yang berarti adanya tekanan kekhawatiran ketegangan pada aspek struktural, memberikan suatu pendekatan analisis terhadap dinamika dan perubahan(Abdulsyani, 2002).

Merton mengutip tiga postulat yang terdapat dalam analisa fungsional yang kemudian di sempurnakan satu demi satu. Postulat pertama adalah kesatuan fumgsional masyarakat yang merupakan suatu keadaan di manaseluruh bagian dari sistem sosial bekrja sama dalam suatu tingkat keselarasan atau konsistensi internal yang memadai, tanpa menghasilkan konflik berkepanjangan yang tidak dapat diatasi atau di atur. Postulat ke dua yaitu fungsionalisme universal, postulat ini menganggap bahwa"seluruh bentuk sosial dan kemudayaan yang sudah baku memiliki fungsifungsi positif". Sebagaimana yang sudah kita ketahui, merton memperkenalkan konsep disfungsi maupun fungsi positif. Beberapa prilaku sosial jelas bersifat disfungsi (Poloma Margaret, 2010).

Merton juga menganjurkan agar elemen-elemen kultural seharusnya di pertimbangkan menurut kriteria keseimbangan konsekuensi-konsekuensi fungsional yang menimbang fungsi positif terhadap fungsi negative. Postulat ke tiga yang melengkapi tiga postulat fungsionalisme adalah postulat indistensability, ia menyatakan bahwa dalam setiap tipe peradaban, setiap kebiasaan, ide, objek material, dan kepercayaaan memenuhi beberapa fungsi penting. Memeiliki sejumlah tugas yang harus dijalankan, dan merupakan bagian penting yang tidak dapat di pisahkan dalam kegiatan sisitem sebagai ke seluruhan (Poloma Margaret, 2010).

Dalam teori Robert King Merton juga memperjelas mengenai disfungsi. Sebagaimana struktur-struktur atau lembaga-lembaga dapat berperan dalam pemeliharaan bagian-bagian lain sistem sosial, mereka juga dapat mempunyai konsekuensi negatif. Menurut Merton sebagaimana struktur atau institusi dapat menyumbangkan pemeliharaan bagian-bagian lain. Dari sistem sosial, struktur atau 
Community: volume 6, nomor 2, Oktober, 2020

p-ISSN: 2477-5746 e-ISSN: 2502-0544

institusi yang dapat menimbulkan akibat negatif terhadap perubahan yang terjadi pada satu bagian yang akan membawa perubahan terhadap bagian lain. Asumsi pada dasarnya bahwa setiap struktur dalam sistem sosial, fungsional terhadap yang lain. Sebaliknya kalau tidak fungsional maka struktur itu tidak akan ada atau hilang dengan sendirinya (Ritzer, 2012).

Menyikapi yang dimaksud oleh Robert K Marton dimana setiap sistem sosial yang ada atau fungsional disisi lain juga memiliki fungsi negaif atau disfungsi. Jika teori inidikaitkan dengan permasalahan yang diteliti maka terdapat bagian dari sistem sosial yaitu sub-sub sistem yang tidak berfungsi dengan baik menyebabkan terjadinya disfungsi. Dikatakan disfungsi karena adanya perubahan di dalam struktur atau sistem yang mengakibatkan adanya ketidak harmonisan didalamnya. Terjadinya perubahan kemunduran bagi kelompok tani di Nagari Pasir Talang kecamatan sungai pagu, kabupaten solok selatan. Baik secara eksternal maupun internal. Perubahan tersebut terjadi secara disfugsi yang diiringi dengan tugas fungsinya yang tidak berjalan dengan baik didalam kelompok tani. Berarti ada sub sistem yang tidak berjalan dengan baik, sehingga pembangunan suatu Kelompok Tani tidak berjalan sesuai dengan tujuan yang hendak di capai oleh suatu kelompok(Mubyarto, 1989).

\section{METODE PENELITIAN}

Pendekatan yang digunakan dalam penelitian ini adalah kualitatif. Pendekatan penelitian kualitataif merupakan sebuah pendekatan penelitian mengenai ilmu-ilmu sosial yang mengumpulkan dan menganalisis sebuah data tersebut dalam bentuk kata-kata (berbentuk lisan ataupun tulisan) dan perbuatan yang dilakukan oleh manusia serta peneliti yang berudaha tidak menghitung atau mengkualifikasikan data kualitatif tersebut yang telah diperolehnya dengan demikian penelitian ini tidak menganilisis angka-angka (Afrizal, 2014)

Penggunaan metode penelitian kualitatif karena esensi data yang akan dikumpulkan harus dianalisis oleh peneliti. Metode penelitian kualitatif data yang hendak dikumpulkan dan dianalisis merupakan data yang berupa kata-kata dan perbuatan manusia (Bungin, 2010). Data yang akan dikumpulkan dan dianalisis adalah makna yang diberikan oleh individu-individu terhadap sesuatu dan konteks sosial makna tersebut atau bagaimana manusia memperoleh makna itu (Emzir, 2012). Pengetahuan manusia dan cara manusia menggunakan pengetahuan tersebut dalam kehidupan mereka. Proses terjadinya sesuatu dan kaitannya dengan lingkungan sosial kejadian tersebut. Kedua pertimbangan teoritis dan pandangan terhadap ilmu (Afrizal, 2014)

\section{TEMUAN DAN PEMBAHASAN}

\section{A. Faktor Penyebab Kemunduran Kelompok Tani di Nagari Pasir Talang}


Berbagai faktor penyebab kemunduran yang peneliti temui di lapangan. Berdasarkan hasil observasi dan wawancara yang telah peneliti lakukan peneliti menemukan banyak permasalah yang di alami oleh kelompok tani yang ada di Nagari Pasir Talang. Salah satu penyebabnya yaitu ketidakjelasan mengenai keuangan kelompok tani.

\subsection{Kurangnya Transparansi Keuangan dalam Kelompok Tani}

Transparasi sangat dibutuhkan terutama dalam mengembangkan usaha dan untuk menjaga kepercayaan. Berdasarkan peraturan pemerintah Nomor 71 Tahun 2010, transparasi berarti memberikan informasi keuangan yang terbuka dan jujur kepada masyarakat berdasarkan pertimbangan bahwa masyarakat memiliki hak untuk mengetahui secara terbuka dan menyeluruh atas pertanggung jawaban terhadap pengelolaan sumber daya yang ada berdasarkan perundang-undangan. berdasarkan peraturan pemerintah di atas mengenai transparasi keuangan, bahwa informasi yang jelas mengenai catatan keuangan sangat di perlukan guna menjaga kepercayaan anggota. Transaparansi keuangan dalam anggota kelompok tani juga di perlukan. Berdasarkan surat pengukuhan pasal 10 mengenai tugas bendahara, di mana bendahara memiliki tugas membuat laporan keuangan dan catatan-catatan keuangan dengan jelas.

Berdasarkan wawancara peneliti dengan bendahara kelompok tani Tunas Muda, ketika peneliti meminta bukti catatan keuangan kelompok bendahara tersebut tidak bisa melihatkan catatan-catatan atau bukti laporan keuangan kelompok. Ketidak jelasan catatan laporan keuangan kelompok maka timbul permasalahan-permasalahan yang di hadapi oleh kelompok tersebut, seperti yang di ungkapkan oleh Bapak Haini (63 tahun) sebagai anggota kelompok tani Tunas Muda:

Keuangan kelompok tani ini tidak jelas, tidak ada catatan-catatan yang jelas dari pengeluaran ataupun pemasukan keuangan kelompok. berapa uang masuk dan uang keluar dari hasil panen kami sebagai anggota tidak tau. Di samping itu setiap kali pertemuan yang biasa di lakukan satu bukan dua kali pertemuan kami menyumbang untuk uang kas sebesar lima ribu rupiah.

Hal yang sama juga di paparkan oleh anggota kelompok tani tunas muda yaitu eti (60 tahun) berikut hasil wawancara peneliti dengan Ibuk Eti

Saya sebagi anggota kelompok tani tidak mengetahui dengan jelas jumlah keuangan kelompok tani sampai sat ini. Saya tau uang kelompok tani itu ada tpi jumlah dari uang tersebut saya tidak mengetahuinya. Dan uang tersebut di pergunakan untuk apa saya tidak tau. Saya sebagai anggota kelompok mengikuti prosedur saja"

Berdasarkan hasil wawancara di atas dapat di simpulkan yaitu salah satu faktor kemunduran kelompok tani yaitu mengenai kurangnya transparasi keuangan kelompok tani. Berdasarkan surat pengukuhan kelompok terdapat 
Community: volume 6, nomor 2, Oktober, 2020

p-ISSN: 2477-5746 e-ISSN: 2502-0544

aturan-aturan yang tertulis mengenai keungan kelompok tani. Menurut peraturan pengukuhan tugas utama bendahara yaitu memegang keuangan kelompok tani, membuat laporan keuangan sesuai dengan pengeluaran dan pemasukian keungan kelompok dan anggota wajib mengetahui mengenai keuangan. Peraturan tersebut di buat guna menghindari penyalahgunaan keuangan yang sudah ada. Sedangkan menurut hasil wawancara di atas anggota kelompok tidak mengetahui berapa jumlah keuangan karena tidak ada catatan yang jelas mengenai keuangan kelompok. Sehingga menimbulkan permasalahan seperti ketidakpuasan anggota kelompok, apabila bagian dari anggota kelompok tidak puas maka akan mepengaruhi keberlangsungan anggota tersebut. Tranparansi dalam sebuah organisasi merupakan sebuah ciri dan tanda bahwa organisasi tersebut sehat. Dalam organisasi masyarakat selama ini hal tersebut merupakan sebuah kendala yang harus ditemukan titik temunya (Yosefrizal, Sabar, 2012). Dari permasalahan di atas dapat di simpulkan bahwa sub sistem yang tidak berjalan dengan baik, yaitu bendahara tidak menjalankan fungsinya sehingga timbul permasalahn yang mengakibatkan disfungsi dalam kelompok.

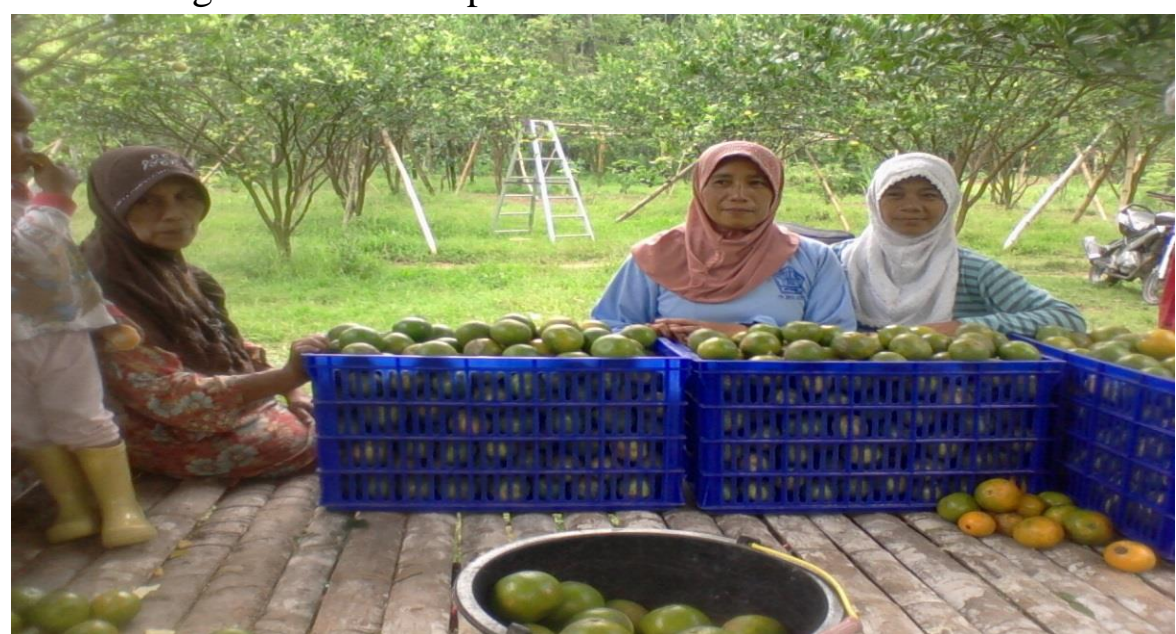

Gambar 4.1 Kegiatan Pemanenan Jeruk Kelompok Tani Tunas Muda

\subsection{Kurangnya Koordinasi Antara Kelompok Tani Dengan Wali Nagari Pasir Talang}

Koordinsai ialah kegiatan yang di kerjakan oleh banyak pihak dari satu organisasi yang sederajat dan untuk mencapai tujuan bersama dengan kesepakatan masing-masing pihak agar tidak terjadi kesalahan dalam bekerja baik menggangu pihak yang satu dengan pihak yang lainnya. Secara umumnya menyelaraskan kegiatan kerja dari satu pihak ke pihak lainnya. Berdasarkan studi dokumen yang peneliti dapatkan tugas utama Wali Nagari sebagai pelindung, penasehat dan Pembina. Maka dari itu ssuai dengan yang telah di jabarkan maka perlunya koordinasi antara kelompok tani dan Wali Nagari. Dalam kelompok tani perlu 
koordinasi yang baik agar tercapainya tujuan bersama dan keberhaislan masingmasing pihak untuk menentukan hasil akhirnya. Seperti hasil wawancara peneliti dengan Bapak Novri Wandra (45 tahun) sebagai Bapak Wali Nagari Pasir Talang:

Saya sebagai Wali Nagari Pasir Talang melihat kurangnya koordinasi antara kelompok tani dengan pihak wali nagari pasir talang. padahal, posisi kami yaitu sebagai panasehat dan pelindung kelompok tani di nagari pasir talang. sebaiknya apapun kegiatan yang akan di kerjakan oleh kelompok tani ini kami selaku penasehat dan pelindung kelompok tani di libatkan. Guna lebih mengarahkan lagi, seperti mengajukan proposal sebaikanya kami di beri tahu bantuan apa yang di peroleh dan berapa jumlah bantuan itu.

Berdasarkan wawancara di atas dapat di tarik kesimpulan yaitu kurangnya koordinasi kelompok tani dengan pihak wali nagari, di mana wali nagari di sini berfungsi sebagai penasehat dan pelindung kelompok tani. Agar lebih baik lagi hendaknya komunikasi antara kelompok tani dengan wali nagari berjalan dengan baik. Setiap kelompok menerima bantuan lebih baik melapor ke wali nagari agar fungsi wali nagari tidak hilang. Bukan hanya itu wali nagari sebagai pihak pelindung dan penasehat sesuai yang telah di tetapkan oleh studi dokumen yaitu berdasarkan surat pengukuhan kelompok di sana terdapat aturan tersebut.

\subsection{Anggota Kelompok Tani Memiliki Keanggotaan Ganda}

Mematuhi segala peraturan yang telah ditetapkan agar kelompok tani berjalan dengan baik. Pada dasarnya masing-masing kelompok tani telah memiliki aturan untuk kelompok mereka, salah satunya aturan untuk anggta kelompok. dalam mencapai tujuan hendaknya harus terfokus kepada suatu pekerjaan. Beberapa anggota tani ada yang memiliki keanggotaan ganda dalam kelompok tani Tunas Muda, mereka tergabung dalam dua kelompok tani sekaligus. Sehingga terganggunya kegiatan kelompok yang mana kelompok tidak menjalankan tugasnya dengan baik karna harus membagi waktunya, menurut Merton Sub sistem tidak berjalan dengan baik dikarenakan bagian dari sistem melakukan sesuatu di luar aturan sisitem dan menggangu kegiatan kelompok. maksud dan tujuan anggota seperti ini yaitu salah satunya untuk mendapatkan bantuan. Dengan begabung di dua kelompok tentunya mendapat bantuan lebih. Berikut hasil wawancara peneliti dengan Bapak Atrial (50 tahun) ketua kelompok tani Tunas Muda, berikut hasil wawancara dengan ketua kelompok Tunas Muda:

Anggota kelompok tani ada yang melanggar aturan kelompok yang telah di sepakati sebelumnya. Ada anggota yang bergabung di dalam dua kelompok tani secara bersamaan. Padahal aturan dalam kelompok tani ini sudah di buat dan di sepakati yaitu hanya tergabung dalam satu kelompok tani saja, dan setia kepada kelompok nya. Tidak bisa dalam satu orang dapat fokus dalam dua kelompok tani. Dalam satu kelompok tani saja sudah kewalahan" 
Community: volume 6, nomor 2, Oktober, 2020

p-ISSN: 2477-5746 e-ISSN: 2502-0544

Berdasarkan hasil wawancara di atas dapat di simpulkan yaitu faktor kemunduran kelompok tani di karenakan anggota yang bergabung dengan dua kelompok tani yang berbeda, di dalam berkelompok, dia berkelompok lagi dengan kelompok lainnya, hal tersebut yang membuat sistem dalam kelompok tersebut tidak berjalan dengn baik, menurut Merton, apabila Sub sistem tidak berjalan dengan baik maka akan mempengaruhi kelompok tersebut (Poloma, 2000). Bisa di lihat dari aturan yang telah di buat di mana dalam aturan itu tertulis larangan untuk tergabung dengan dua kelompok tani yang berdeda. Berarti di sini anggota kelompok telah melakukan disfungsi karena melanggar aturan tertulis. Sehingga dampak buruk terhadap kemajuan kelompok itu.

\subsection{Permasalahan Lahan yang digarap Oleh Kelompok Tani}

Lahan merupakan hal yang paling penting yang harus di perhatikan oleh kelompok tani, secara keseuruhan kelompok tani dalam mengembangkan usaha taninya tidak memiliki lahan sendiri, tetapi kelompok tani menyewa lahan sesuai dengan kesepakatan yang telah di buat antara kelompok dan si pemilik lahan. Berdasarkan studi dokumen mengenai syarat-syarat penyewahan lahan yang telah disepakati oleh kelompok dan oleh si pemilik lahan, yaitu lahan akan di kembalikan jika tidak memiliki penghasilan lagi. Selama tanaman masih menghasilkan atau masih bisa dipanen dan belum mati tanamannya, maka pemilik tanah tidak berhak mengambil lahan tersebut (Sri Rahmadani, 2017). Tetapi apabila lahan tersebut sudah tidak menghasilkan atau tanaman sudah mati, maka lahan akan diambil alih oleh pemiliknya. Saat lahan sudah diambil alih maka akan menyebabkan kelompok tersebut tidak memiliki lahan untuk bercocok tanam lagi. Berikut hasil wawancara peneliti dengan ketua kelompok tani suka maju yaitu Bapak Buswardi (64 tahun). Berikut hasil wawancara dengan Bapak Buswardi:

Lahan yang di garap adalah lahan yang di sewah, bukan lahan pribadi kelompok. dalam pentyewaan lahan tentunya ada kesepakatan yang kami buat dengan pemlik lahan. Kesepakatan kami buat secara tertulis yatu si pemilik lahan tidak berhak mengambil lahan secara sepihak, selama tanaman masih menghasilkan lahan masih berhak di garap oleh kelompok tani. Permasalahnnya di sini masalah jeruk yang tidak berpenghasilan lagi, bisa di katakana sudah mati. Dan lahan di kembalikan ke pemiliknya”

Berdasarkan hasil wawancara di atas dapat kita tarik kesimpulan yaitu salah satu faktor penyebab kemunduran kelompok tani dalam mengembangkan usaha tani yaitu kepemilikan lahan, di mana lahan yang digarap tidak milik kelompok tetapi disewa. Proses penyewaan pun berdasarkan kesepakatan yang telah dibuat yaitu lahan yang digarap seumur tanaman, pemilik tidak berhak mengambil lahan secara sepihak dikala tanaman masih menghasilkan, yang menjadi permasaahan di sini lahan yang digarap tidak berpenghasilan lagi, di 
mana tanaman jeruk yang sudah mati dan tidak terawat lagi. maka dari itu lahan dikembalikan lagi ke pemiliknya. Saat kelompok tani sudah tidak miliki lahan lagi sudah dipastikan kelompok tani itu tidak akan berjalan lagi atau tidak aktif. Permasalahan ini salah satu penyebabnya yaitu kurangnya perencanaan kedepannya oleh kelompok. seharusnya kelompok bisa mengakalinya dengan menanam tanaman lain, atau melakukan peremajaan.

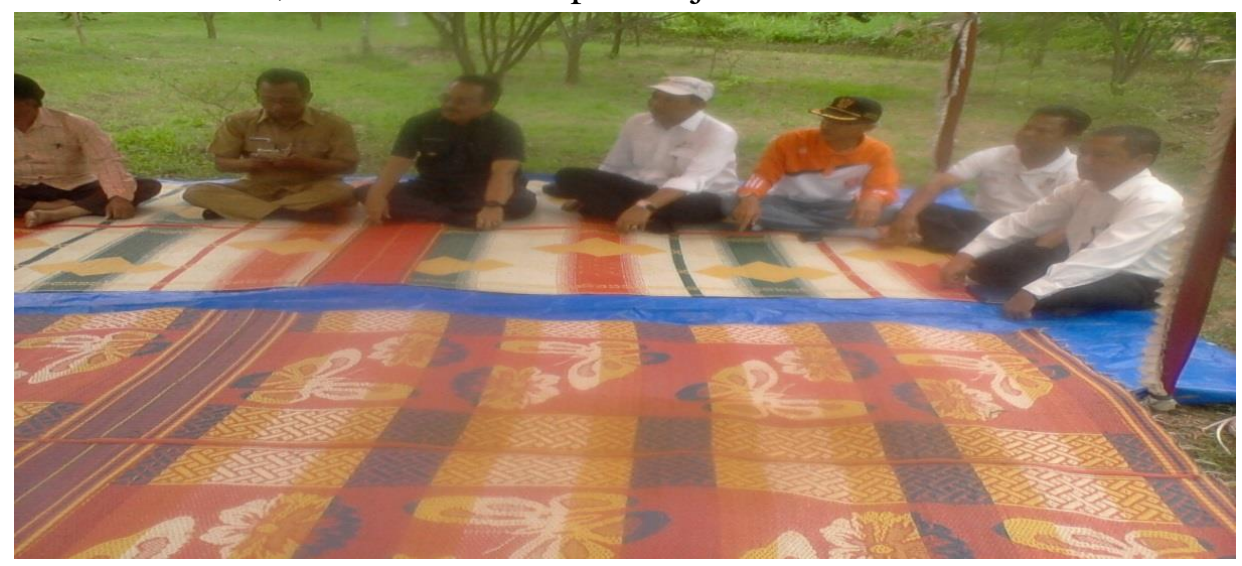

Gambar 4.2 Kegiatan Rapat Kelompok Tani Suka Maju

\subsection{Gapoktan Belum Menjalankan Fungsinya Dengan Baik.}

Gapoktan merupakan gabungan dari kelompok tani yang mempunyai peran dan fungsi memfasilitasi pemecahan kendala atau permasalahan yang dihadapi oleh petani dari berbagai kelompok tani yang tergabung dalam gapoktan. Gapoktan membantu memasarkan hasil pertanian melalui sistem penjualan dan pembelian. Gapoktan diharapkan bisa menjalankan fungsi kemitraan dengan adil dan saling menguntungkan (Syahyuti, 2007).

Berdasarkan hasil wawancara dengan Bapak Benriono (40 tahun) ketua kelompok tani Usaha Baru yakni:

Fungsi gapoktan di nagari kita, tidak ada. Gapoktan yang diharapkan sebagai pemecah masalah yang dihadapi oleh petani, baik permasalahan pengelolaan kelompok sampai permasalahan kemitraan. Tugas itu lah yang tidak ada padahal gapoktan ini keberadaannya sangat di butuhkan"

Pemaparan yang sama juga di sampaikan oleh Bapak Hendri (35 tahun) sebagai anggota kelompok tani Berkat Yakin, sebagai berikut:

Saya menilai fungsi gapoktan memang tidak ada bisa saya rasakan. Gapoktan di nagari saya sudah tidak berfungsi lagi. kepengurusan gapoktan tidak jelas. Sepertinya dengan fakumnya gapoktan tidak ada perencanaan untuk mendirikan gapoktan lagi"

Berdasarkan hasil wawancara di atas dapat kita tarik kesimpulan yaitu tidak berfungsinya gapoktan di Nagari Pasir Talang, sehingga tugas gapoktan 
Community: volume 6, nomor 2, Oktober, 2020

p-ISSN: 2477-5746 e-ISSN: 2502-0544

sebagai pemecah masalah dalam kelompok, dan sebagai pencari mitra usaha dalam kelompok tidak berfungsi lagi. Gapoktan yang memiliki posisi sebagai institusi yang mengkoordinasi lembaga-lembaga fungsional di bawahnya yaitu kelompok tani (Syahyuti, 2007). Dengan berbagai fungsi gapoktan untuk menjalin koordinasi atau hubungan kelompok.

\section{PENUTUP}

Berdasarkan hasil penelitian, dapat disimpulkan bahwa banyak faktor penyebab kemunduran kelompok tani karena adanya sub sistem yang tidak menjalankan fungsinya. Ketua dan bandahara tidak menjalankan fungsinya terkait dengan pencatatan-pencatatan keuangan, di mana tidak ada catatan-cartatan keuangan yang jelas, bukan hanya itu koordinasi dengan pihak lain tidak ada, dan anggota kelompok tani tidak juga mematuhi peraturan yang telah di sepakati. Juga permasalahan seperti lahan yang digarap oleh kelompok, dan tidak ada program perencanaan pembangunan kelompok tani tersebut. Anggota kelompok tani memiliki keanggotaan ganda. Gapoktan perlu menjalankan fungsinya. Tidak berjalannya peran masing-masing anggota kelompok yang menyebabkan disfungsi.

\section{DAFTAR PUSTAKA}

Abdulsyani (2002) Sosiologi Skema, Teori dan terapan. Jakarta: PT Bumi Aksara.

Afrizal (2014) metode penelitian kualitatif. Jakarta: Rajawali Pers.

Akbar, Waza Karia (2018) 'Socio-economic Dependence of Peasant to Local Collector on Rice Farming System', Jurnal Ilmu Sosial Mamangan, 7(1), pp. 23-31.

Alhafis. (2016) Kemampuan Kelompok Tani Dalam Mendukung Pengembangan Sayuran. Riau: Universitas Riau.

Bungin, B. (2010) Penelitian Kualitatif: Komunikasi Ekonomi, Kebijakan Publik dan Ilmu Sosial lainnya, Edisi ke-2. Jakarta: Kencana Prenada Media Group.

Emzir (2012) Analisis Data: Metode Penelitian Kualitatif. Jakarta: Rajawali Pres.

Mawarni, Eka, Mahludin Baruwadi, and I. B. (2017) 'Peran Kelompok Tani Dalam Peningkatan Pendapatan Petani Padi Sawah Di Desa Iloheluma Kecamatan Tilongkabila Kabupaten Bone Bolango', Jurnal Agrinesia, 2(1).

Mubyarto (1989) Pengantar Ekonomi Pertanian. Jakarta: LP3ES.

Poloma, M. (2000) Sosiologi Kontemporer. Jakarta: CV. Rajawali Pres.

Poloma Margaret (2010) Sosiologi Kontemporer. Jakarta: PT. Raja Grafindo.

Ritzer, G. (2012) Teori Sosiologi Modern. Jakarta: Prenada Media.

Sri Rahmadani (2017) 'Analisis Struktur-Agensi Sumber Pendapatan Ganda Petani Miskin’, Jurnal Ilmu Sosial Mamangan, 6 ( 1 ), pp. 11-22.

Syahyuti (2007) Kebijakan Pengembangan Gabungan Kelompok Tani (GAPOKTAN) sebagai Kelembagaan Ekonomi di Pedesaan. Bogor: Pusat Analisis Sosial Ekonomi dan Kebijakan Pertanian. 
Community: volume 6, nomor 2, Oktober, 2020

p-ISSN: 2477-5746 e-ISSN: 2502-0544

Triwidarti, T. (2015) 'Peran Kelompok Tani Sempurna Dalam Meningkatkan Pengetahuan Petani Dan Hasil Produksi Padi', Jurnal Ar Ilmiah, 5(1).

Yosefrizal, Sabar, W. (2012) 'Pasang Surut Sosial Ekonomi Petani Cengkeh Di Nagari Koto Anau, kec. Lembang', Jurnal Ilmu Sosial Mamangan, 1 ( 2), pp. 85-94. 